Meta

Journal des traducteurs

Translators' Journal

\title{
An Account on Translators' and/or Terminologists' Training at the Universities of Yarmouk and Jordan
}

\section{Lutfi A. Abulhaija}

Volume 37, numéro 2, juin 1992

URI : https://id.erudit.org/iderudit/001850ar

DOI : https://doi.org/10.7202/001850ar

Aller au sommaire du numéro

Éditeur(s)

Les Presses de l'Université de Montréal

ISSN

0026-0452 (imprimé)

1492-1421 (numérique)

Découvrir la revue

Citer cet article

Abulhaija, L. A. (1992). An Account on Translators' and/or Terminologists' Training at the Universities of Yarmouk and Jordan. Meta, 37(2), 368-370. https://doi.org/10.7202/001850ar
Résumé de l'article

On présente le programme de formation des traducteurs et / ou terminologues dans les universités de Yarmouk et de Jordanie. On explicite les conditions d'admission, les cursus, les méthodes d'enseignement, les diverses orientations offertes... 


\section{BLOC-NOTES}

\section{AN ACCOUNT ON TRANSLATORS' AND/OR TERMINOLOGISTS' TRAINING AT THE UNIVERSITIES OF YARMOUK AND JORDAN}

Résumé

On présente le programme de formation des traducteurs et / ou terminologues dans les universités de Yarmouk et de Jordanie. On explicite les conditions d'admission, les cursus, les méthodes d'enseignement, les diverses orientations offertes...

\section{Abstract}

This article is an account on translators' and/or terminologists' training at both Yarmouk University and the University of Jordan. This account is an attempt to give an idea about training programmes, syllabi, registration prerequisites, teaching methods, degrees and other relevant information. Information was derived through personal contacts with the programmes concerned.

\section{INTRODUCTION}

It is to be stated right at the outset of this article that the English Departments at both universities - Yarmouk and Jordan - play rather an insignificant role in training translators and terminologists. The Department of English at the University of Jordan offers two translation courses at the undergraduate level aiming at teaching the basic principles of translation. On the other hand, the Department of English at Yarmouk University offers just one translation course at the undergraduate level, which also focuses upon the basic elements of translation. Moreover, the Jordanian Royal Society largely contributes to the translation of specialized material (Abulhaija 1989). These three centres are the only places where students are being trained in translation. However, translation training is being taught more thoroughly at the graduate level at both universities where an M.A. degree and a high diploma in translation are granted, i.e., professional translators are thus being trained \& taught. The focus in the rest of this paper will then be upon the major centres of translator training at both Jordanian universities, namely, the Language Centres at both universities since they are virtually in charge of teaching and training translators at the professional and academic levels.

\section{YARMOUK UNIVERSITY (YU)}

Translation from and into Arabic and English has only been recently introduced into the academic curriculum of Yarmouk University Language Centre. An M.A. programme in translation was started in September (Sawaf and Abulhaija 1987). The following will be a briefing about this programme:

An M.A. degree in translation from Arabic into English and vice versa after completing the following course requirements successfully will be awarded.

\section{(a) Orientation Courses ( 6 credit hours):}

- TRA 400: Writing Skills in English (3 credit hours)

The aim of this course is to teach students how to write coherent, idiomatic, and effective expository and argumentative prose. Students will be required to write a minimum of fifteen compositions. Student work will be corrected by the instructor and discussed in class. By the end of the course, students are expected to be able to write coherent and well-organized texts which are approximately 600 words long.

- TRA 401: Writing Skills in Arabic (3 credit hours) (Same description as TRA 400 above except for Arabic as a medium of expression).

(b) 30 credit hours with an cumulative average not less than $\mathbf{7 5 \%}$ distributed as follows:

(I) Core courses ( 21 credit hours). These are described as follows:

- TRA 501: General Translation from English into Arabic ( 3 credit hours)

Exercises in the translation of factual texts culled from newspapers, magazines, correspondence, etc.

- TRA 502: General Translation from Arabic into English ( 3 credit hours) 
Written translation from Arabic into English of a variety of texts in the areas of literature, civilization and thought, economics, politics, commerce, agriculture, medicine, law, etc. (Prerequisite TRA 501)

- TRA 511: Technical Translation from English into Arabic ( 3 credit hours)

Introduction to the translation of political, economic, business, administrative, advertising texts and the like. Emphasis on vocabulary and phraseology; exercises dealing with translation problems peculiar to such texts. (Prerequisite: TRA 501 and TRA 502)

- TRA 520: Contrastive Arabic - English Linguistics ( 3 credit hours)

A contrastive study and analysis of basic Arabic and English syntactic patterns with emphasis on problems translators face in vocabulary, grammar and style. Workshop course tailored to the needs of future translators.

- TRA 560: Translation Theory ( 3 credit hours) An examination of the aims, doctrines, and methods of translation. Emphasis will also be on social functions and social norms of translation, and the relevance of psycholinguistic and sociolinguistic research to translation and interpretation. (Prerequisite: TRA 501)

- TRA 570: Practical Training in Consecutive Interpretation ( 3 credit hours)

Language Lab. training and practice in listening comprehension and note-taking. Students are expected to spend three hours a week practising consecutive interpreting in the Language Lab. Students will also be given a basic theoretical grounding in the principles and techniques of consecutive interpreting. (Prerequisite: TRA 520 and TRA 560)

- TRA 571: Practical Training in Simultaneous Interpretation ( 3 credit hours)

Language Lab. training and practice in simultaneous interpreting. Students will also be given a basic theoretical grounding in the principles and techniques of simultaneous interpreting. (Prerequisite: TRA 520 and TRA 560)

(II) Elective Courses ( 9 credit hours). These can be chosen from the following courses:

- TRA 524: Contrastive Terminology (3 credit hours)

Contrastive study of Arabic and English lexicons, compilation of bilingual glossaries by the accepted methods of lexicographic and terminological research and analysis of technical dictionaries and the tools of the translator. (Prerequisite: TRA 501 and TRA 502)

- TRA 531: Editing of Oral and Recorded Texts ( 3 credit hours)

Principles and methods of writing and editing oral and recorded English and Arabic texts at the level of the paragraph, the essay, and the short report. (Prerequisite: TRA 501)
- TRA 540: Semantics (3 credit hours)

An advanced course in the study of meaning and meaning relations. The course starts with a review of the basic semantic concepts, notably reference, detonation and connotation, sense relations, and the role of semantics in the study of language. The course also deals with social meaning, affective meaning, meaning by collocation, componential analysis and semantic fields. The course might end with a study of the relationship between lexical and grammatical meaning.

Both Arabic and English texts will be assigned for semantic study and analysis.

- TRA 541: Pragmatics (3 credit hours)

This course concerns the choice of language in speech and writing and the factors that constrain what is said or written. It deals with the norms which have to be observed in the selection of various components of language, as well as the subtle strategies that govern behaviour in language to effect appropriateness and acceptability

- TRA 551: Text Analysis and Translation (3 credit hours)

This course is concerned with detailed analysis of yaried written and recorded texts in Arabic and English. Different varieties of oral and written styles and their functions in both languages will be analysed and studied with particular reference to translation.

- TRA 591: Special Subject in Translation (3 credit hours)

(III) Passing a comprehensive examination in Translation.

(IV) Writing and successfully defending an M.A. thesis in translation ( 6 credit hours)

\section{UNIVERSITY OF JORDAN (UJ)}

A higher institute for translation attached to the Language Centre at the University of Jordan was established back in 1981 (Abulhaija 1987). This institute offers a high diploma in translation. Students ought to successfully complete the following course requirements. ( 45 credit hours):

(a) Orientation Courses (15 credit hours): - TRA 103 Lessons in Arabic: (6 credit hours) - TRA 104 Lessons in English: (9 credit hours)

(b) General Core Courses (27 credit hours):

- TRA 211 Arabic culture: ( 3 credit hours)

- TRA 212 Foreign Culture: ( 3 credit hours)

- TRA 231 Written Translation into Arabic ( 3 credit hours) (See description above)

- TRA 232 Written Translation from Arabic ( 3 credit hours) (See description above)

- TRA 341 Principles of Consecutive Translation ( 3 credit hours) (See description above)

- TRA 311 Foreign Culture (3 credit hours) (See description above) 
- TRA 321 Idioms and Dictionaries (3 credit hours) (See description above)

- TRA 331 Specialized Translation into Arabic ( 3 credit hours) (See description above)

- TRA 341 Simultaneous Interpretation (3 credit hours) (See description above)

(c) Students ought to choose one of the following sets:

(i) Written Translation

(ii) Oral Translation

The student's results in both TRA 241 and 341 will be the main factor in choosing the required number for the Oral interpretation set (see above).

The core courses for both sets (groups) will be as follows:

First: Core courses for the Written Translation Unit ( 9 credit hours):

- TRA 431 Specialized Translation into Arabic

- TRA 432 Specialized Translation from Arabic

- TRA 451 Project in Written Translation

Second: Core Courses for Oral Interpretation Unit (12 credit hours):

- TRA 441 Consecutive Translation

- TRA 446 Simultaneous Interpretation

- TRA 447 Simultaneous Interpretation

- TRA 452 Project in Oral Interpretation

(d) Elective Courses

(i) The written translation group can choose any of the following courses:

- TRA 433 Literary Translation (3 credit hours)

- TRA 439 Special Topic in Written Translation (3 credit hours)

(ii)All students ought to choose two courses ( 6 credit hours) from among the following:

- TRA 322 Translation Theory ( 3 credit hours)

- TRA 323 Comparative Linguistics (3 credit hours)

- TRA 324 Comparative Methodology (3 credit hours)

- TRA 421 Machine Translation (3 credit hours)

- TRA 433 Literary Translation (3 credit hours)

- TRA 439 Special Topic in Written Translation ( 3 credit hours)

- TRA 449 Special Topic in Oral Translation ( 3 credit hours)

Notes

- Instructors decide on their own textbooks, instruction methods, exams and grade distribution.

- Some course descriptions are detailed; others are very brief. This is due to the nature of the material obtained from both universities.

\section{Acknowledgements}

Thanks are due to both Dr. Rajai Khanji from the University of Jordan and Dr. Moh'd Farghal from the Language Center at Yarmouk University for their cooperation in providing the writer with significant information about the translation programmes at both universities.

\section{BIBLIOGRAPHY}

ABULHAIJA, L.A. (1989): "The Role of the English Departments at the Arab Universities in Educating and Training Specialized Translator," Nouvelles de la FIT Newsletter, VIII-1/2.

SAWAF, H. and A. ABULHAIJA, A. (1987): Towards a better approach to translation, Adaab AlRafidein, 1, Mousel University, Mousel.

LUTFI A. ABULhaiJa Yarmouk University, Irbid, Jordan 